\title{
FERTILITY PRESERVATION \\ Follicle reserve loss in ovarian tissue transplantation
}

\author{
Hadassa Roness ${ }^{1}$ and Dror Meirow ${ }^{1,2}$ \\ ${ }^{1}$ Center for Fertility Preservation, Sheba Medical Center, Tel Hashomer, Israel and ${ }^{2}$ Sackler School of Medicine, Tel \\ Aviv University, Tel Aviv, Israel \\ Correspondence should be addressed to D Meirow; Email: dror.meirow@sheba.health.gov.il
}

This paper forms part of an anniversary issue on Fertility Preservation. The Guest Editor for this section was Professor Roger Gosden, College of William and Mary, Williamsburg, Virginia, USA

\begin{abstract}
Ovarian tissue cryopreservation and transplantation (OTCP-TP) has progressed over the past decade from a revolutionary experimental procedure to a well-accepted treatment in many centers for young patients with a high risk of ovarian failure after cancer treatment. The procedure is remarkably successful, with studies reporting return of ovarian function in up to $95 \%$ of graft recipients and pregnancy rates of between $\mathbf{3 0}$ and $\mathbf{5 0} \%$. The most significant limitation of OTCP-TP is the massive loss of follicles that occurs following transplantation, which is primarily attributed to ischemic damage and follicle activation. We review the current approaches to reducing follicle loss and maximizing graft lifespan via pharmacological agents which reduce ischemic damage and follicle activation. We further discuss the value and disadvantage of inducing follicle activation in the graft as a means of generating mature follicles in the immediate short term.

Reproduction (2019) 158 F35-F44
\end{abstract}

\section{Introduction}

Since the first successful live births post transplantation of cryopreserved stored ovarian tissue (Donnez et al. 2004, Meirow et al. 2005), ovarian tissue cryopreservation and transplantation (OTCP-TP) has progressed from a revolutionary experimental procedure to a wellaccepted treatment in many centers for young patients with a high risk of ovarian failure after cancer treatment. Hundreds of graft transplantations have been performed to date, with a pregnancy rate of between 30 and 50\% and over 130 live births (Gellert et al. 2018). In some countries OTCP has become standard care covered by national health authorities (Meirow et al. 2016). There has been no reported increase in rate of birth defects or other abnormalities in children born from transplanted ovarian tissue (Rodriguez-Wallberg et al. 2016). Ovarian tissue cryopreservation is most commonly performed for medically indicated fertility preservation in young cancer patients facing potentially ovotoxic treatments. Although return of ovarian function occurs in $95 \%$ of ovarian tissue transplantations, the duration of graft survival is variable; in some cases, a single graft has maintained function for years, producing as many as four consecutive pregnancies, while other grafts cease functioning within a few months (Andersen et al. 2012, Donnez \& Dolmans 2015, Meirow et al. 2016). The total number of follicles present in any particular graft is influenced by patient age, natural variability, exposure to chemotherapy treatments prior to tissue harvesting as well as graft dimensions. However, while these factors define the initial starting reserve in the graft, many studies have shown that the vast majority (approximately 80\%) of these initial follicles are lost through the process of OTCP-TP (Liu et al. 2002, Dolmans et al. 2007, Hancke et al. 2009, Dath et al. 2010, Gavish et al. 2018), such that what ultimately defines the lifespan of the graft is the final number of primordial follicles in the graft after transplantation that survive the procedure. This dramatic loss of follicle reserve is considered a significant limitation of OTCP-TP (Gosden et al. 1994, Nugent et al. 1998, Dolmans et al. 2007); therefore, analysis of the causes of this loss is necessary for the development of new techniques to maximize graft lifespan and optimize OTCP-TP (Kawamura et al. 2015, Silber 2016).

\section{Follicle loss in ovarian transplantation}

OTCP-TP involves a multitude of steps that each contribute to a different extent to the overall decline in follicle numbers (Fig. 1). Briefly, a section of the ovary, or the entire ovary, is removed from the patient, following which the medulla is removed, and the cortex is mechanically thinned so that almost all the larger growing follicles are removed and the remaining tissue 


\section{Loss of ovarian reserve with OTCP and transplantation}
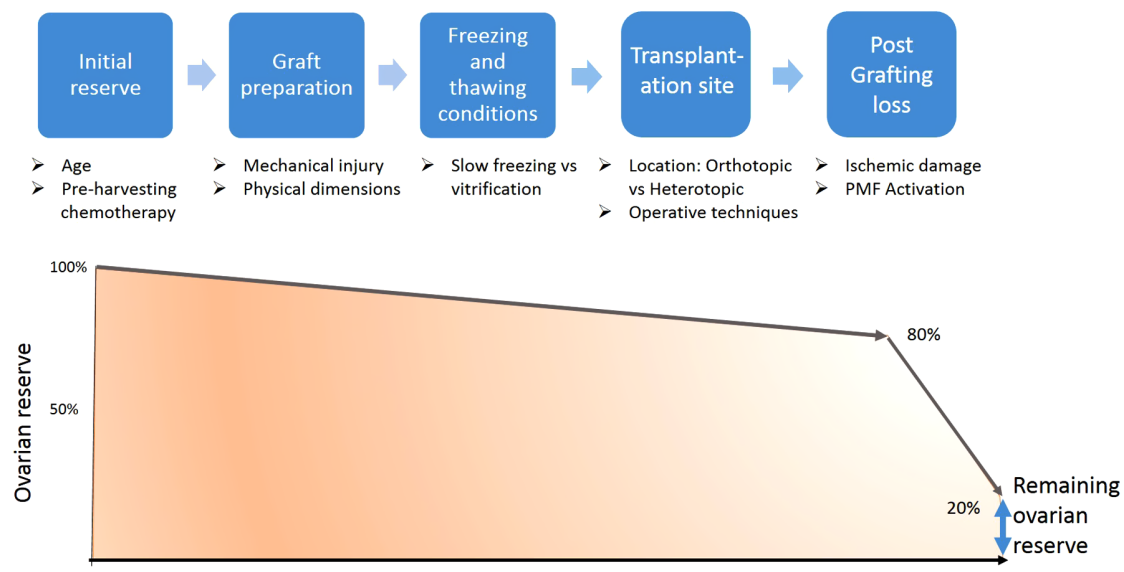

Figure 1 Loss of ovarian reserve with each stage of ovarian tissue cryopreservation and transplantation. Different degrees of follicle loss occur at each stage of the cryopreservation and transplantation procedure and are influenced by specific factors. At each stage of the cryopreservation and transplantation procedure, various factors affect the degree of follicle loss that occurs. However, it is estimated that the vast majority of the $80 \%$ of primordial follicles lost during the procedure are lost in the final post grafting stage. comprises cortical stroma containing mostly primordial as well as some primary and secondary follicles (Donnez \& Dolmans 2010, Lee et al. 2016). The tissue is then equilibrated with cryoprotectants prior to being frozen and stored in liquid nitrogen (almost all OTCP conducted to date has used the slow-freezing protocol, and a comparison of the advantages or disadvantages of slow freezing vs vitrification is beyond the scope of this review). At the time of transplantation the tissue is thawed, washed from the cryoprotectants media and placed into the non-functioning ovary or intraperitoneal pocket, the method used by the first studies which achieved live births using OTCP-TP (Donnez et al. 2004, Meirow et al. 2005).

In order to evaluate graft follicle loss or survival, it is important to differentiate between two different populations of follicles; the dormant primordial follicles that comprise the reserve and the fertility potential of the graft, and the larger, developing follicles. The largest growing follicles, the antral follicles, are lost by mechanical injury during tissue preparation, and smaller growing follicles are lost in the process of cryopreservation since they are highly vulnerable to freezing and thawing (Candy et al. 1997, Baird et al. 1999, Aubard 2003, Liu et al. 2008). This may explain why the return of endocrine function and the production of mature follicles occurs on average 4-5 months after transplantation (Donnez et al. 2013, Silber 2016), a time period that aligns with the 4-6 months that it is believed to take for PMFs to develop to that stage in the human ovary (Gougeon 1986), although this estimate is not absolute. The population of dormant follicles is less susceptible to cryopreservation injury than the developing follicles (Newton et al. 1996, Gosden et al. 2002, Camboni et al. 2008), and studies comparing transplanted fresh and frozen-thawed tissue show similar rates of follicle survival (Amorim et al. 2011) and functioning (Silber 2015), which strengthens the inference that cryopreservation does not contribute greatly to the loss of primordial follicles in tissue grafts. These data are based on small sample sizes, and additional study is needed to clarify this point since it is otherwise possible that the steps of tissue preparation and cryopreservation might induce damage that subsequently predisposes the follicles to die after transplantation, in which case changes in these earlier stages could have a significant impact on follicle survival and graft lifespan.

Studies assessing follicle loss in ovarian tissue grafts indicate that while each step of the OTCP-TP procedure contributes to the loss of primordial follicle reserve, the most significant loss occurs in the post-transplantation period (Fig. 1) (Gosden et al. 1994, Nugent et al. 1998, Aubard et al. 1999, Baird et al. 1999, Dolmans et al. 2007, von Schonfeldt et al. 2012, Gavish et al. 2018). It is estimated that at least $75 \%$ of the follicles which are lost during the process of OTCP-TP are lost during transplantation as the graft re-vascularizes and regains homeostasis in a new environment. For this reason, optimization efforts on the post-transplantation stages are likely to have the greatest impact on the final follicle reserve.

\section{Causes of transplantation-induced primordial follicle loss}

Two mechanisms have been proposed to contribute to the massive follicular loss that occurs post transplantation: ischemia and activation.

Initial removal of the ovary from its blood and oxygen supply begins a period of ischemia that is temporarily paused during cryopreservation, only to continue upon thawing and transplantation (McCord 1985, Van Eyck et al. 2010, Donnez et al. 2013). Follicle survival depends on rescue of the tissue from the initial period of ischemia and hypoxia with neovascularization. The beginnings of neovascularization have been observed 3 days following transplantation of human ovarian tissue onto a chick chorioallantoic membrane (Martinez-Madrid 
et al. 2009), and it is estimated that the transplanted graft exists in a hypoxic environment with nutrients and oxygen supplied via diffusion from surrounding tissue for a period of approximately 3-5 days, (Van Eyck et al. 2009). It can take up to 10 days before revascularization is able to provide full oxygenation and nutrients to the graft (Aubard et al. 1999, Israely et al. 2004, Cacciottola et al. 2018). Angiogenesis from both the host and the graft itself have been shown to contribute to neovascularization of the graft (Van Eyck et al. 2010).

During this period of angiogenesis the grafted tissue is subjected to ischemic reperfusion injury, resulting in the production of inflammatory mediators, free radicals and reactive oxygen species (Demeestere et al. 2009, Commin et al. 2012). Ischemic reperfusion injury has been shown to cause follicle loss primarily via effects on the granulosa cells of growing follicles, while primordial follicles are thought to be less vulnerable to ischemic injury since as dormant cells they have a low metabolic rate (Kim et al. 2004b, Harris et al. 2009, Bols et al. 2010) and are accustomed to a relatively hypoxic environment in the poorly vascularized outer ovarian cortex (Gosden \& Byatt-Smith 1986). Primordial follicles are not entirely resistant to the effects of ischemia; however, as some methods aimed at reducing the ischemic period, there have been improvements in primordial follicle survival in transplanted grafts (Table 1).
Thesignificantprimordial follicles loss thatoccurs shortly after transplantation has been shown to be simultaneously accompanied by a significant increase in early growing follicles populations and increased proliferation of granulosa cells in transitional and early growing follicles (Oktay et al. 2000b, Dolmans et al. 2007, Dath et al. 2010, Amorim et al. 2011, Ayuandari et al. 2016, Gavish et al. 2018) (Fig. 2). Although only proportional increases in growing follicle populations were shown in some of these studies, which could be explained by the loss of PMFs rather than any actual increase in growing follicle numbers, this is unlikely. The process of transplantation causes death of growing follicles, so that if even a similar number of growing follicles are seen in the transplanted tissue this would indicate that some process of activation had occurred. Moreover, most of these studies present evidence of significant proliferation in transitional and early growing follicles (80-95\% of these follicles were shown to be actively proliferating in the transplanted graft, compared to only $18-40 \%$ in untransplanted tissue (Dolmans et al. 2007, Dath et al. 2010)). A significant rise in anti-Mullerian hormone (AMH) was also observed in patients who underwent transplantation of ovarian tissue in the immediate post-transplantation period before subsequently returning to low, sometimes undetectable levels (Silber 2016). These data suggest a phenomenon of mass activation of the PMF pool that occurs immediately

Table 1 Agents tested for use as pharmacological fertility preservation agents in animal studies.

\begin{tabular}{|c|c|c|c|c|}
\hline Substance & Mechanism & Impact on PMF reserve & $\begin{array}{l}\text { Graft } \\
\text { species }\end{array}$ & Study \\
\hline \multicolumn{5}{|l|}{ Increasing vascularization } \\
\hline \multirow[t]{3}{*}{ Stem cells } & Angiogenesis & $\begin{array}{l}\text { Non-statistical decrease in PMF after } 30 \\
\text { days }\end{array}$ & Mouse & Damous et al. 2015 \\
\hline & & Increased PMFs (21 days) & Human & Xia et al. 2015 \\
\hline & & Increased PMFs (7 days) & Human & Manavella et al. 2018 \\
\hline \multirow[t]{4}{*}{ VEGF } & Angiogenesis & Increased PMFs (10 days), no difference & Mouse & Shikanov et al. 2011 \\
\hline & & $\begin{array}{l}\text { Non-statistical increase in } \\
\text { PMF ( } 3 \text { weeks })\end{array}$ & Human & Wang et al. 2013 \\
\hline & & & Sheep & Labied et al. 2013 \\
\hline & & $\begin{array}{l}\text { No assessment of } \\
\text { PMF number }\end{array}$ & Human & $\begin{array}{l}\text { Abir et al. 2011, } \\
\text { Friedman et al. } 2012\end{array}$ \\
\hline \multirow[t]{3}{*}{ bFGF } & Angiogenesis & Increased PMF (6 weeks) & Human & Tanaka et al. 2018 \\
\hline & & Increased PMFs (7 days) & Mouse & Gao et al. 2013 \\
\hline & & No difference & Human & Wang et al. 2013 \\
\hline $\mathrm{FSH}$ & Angiogenesis & No assessment of PMF numbers & Mouse & Ma et al. 2017 \\
\hline Simvastatin, methylprednisolone* & $\begin{array}{l}\text { Angiogenesis, } \\
\text { anti-inflammatory }\end{array}$ & No increase in PMFs (21 days) & Mouse & Lee et al. 2015 \\
\hline \multicolumn{5}{|l|}{ Reducing ischemic injury } \\
\hline Verapamil & Ca channel blocker & Increase PMFs (2 weeks) & Mouse & Saber et al. 2018 \\
\hline \multirow[t]{2}{*}{ Erythropoietin } & Antioxidant & No difference & Canine & Commin et al. 2012 \\
\hline & & Increased PMFs (28 days) & Mouse & Mahmoodi et al. 2014 \\
\hline $\mathrm{N}$-acetylcysteine & Antioxidant & Increased PMFs (28 days) & Mouse & Mahmoodi et al. 2015 \\
\hline \multirow[t]{2}{*}{ Vitamin E } & Antioxidant & $\begin{array}{l}\text { No significant difference } \\
\text { (7 days) }\end{array}$ & Human & Nugent et al. 1998 \\
\hline & & $\begin{array}{l}\text { No assessment of } \\
\text { PMF number }\end{array}$ & Human & $\begin{array}{l}\text { Abir et al. 2011, } \\
\text { Friedman et al. } 2012\end{array}$ \\
\hline S1p & Anti-apoptosis & No assessment of PMF number & Human & Soleimani et al. 2011 \\
\hline GnRH agonist & & Decrease in PMFs (15 weeks) & Human & Maltaris et al. 2007 \\
\hline
\end{tabular}

*Simvastatin and methylprednisolone increase vascularization and reduce ischemic injury. 


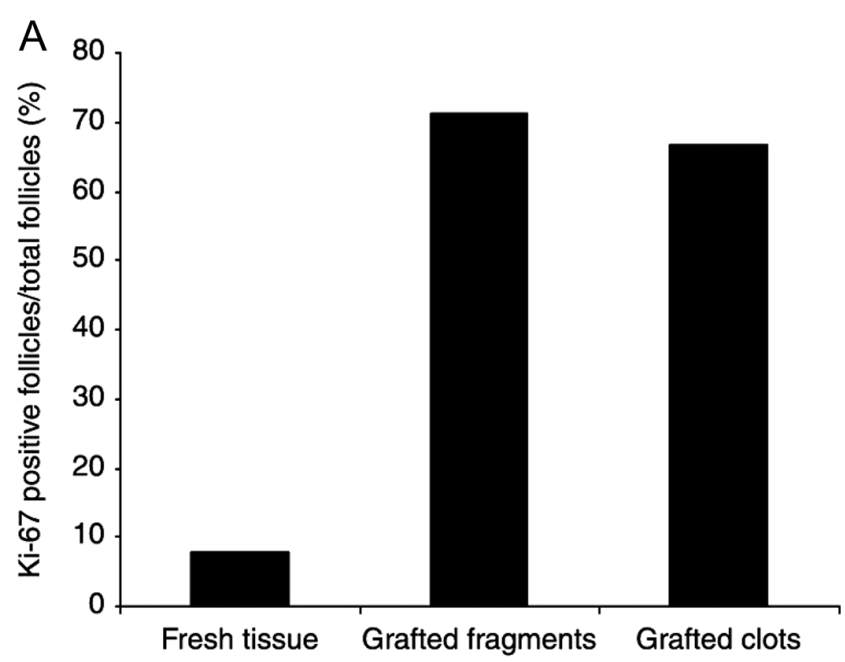

B

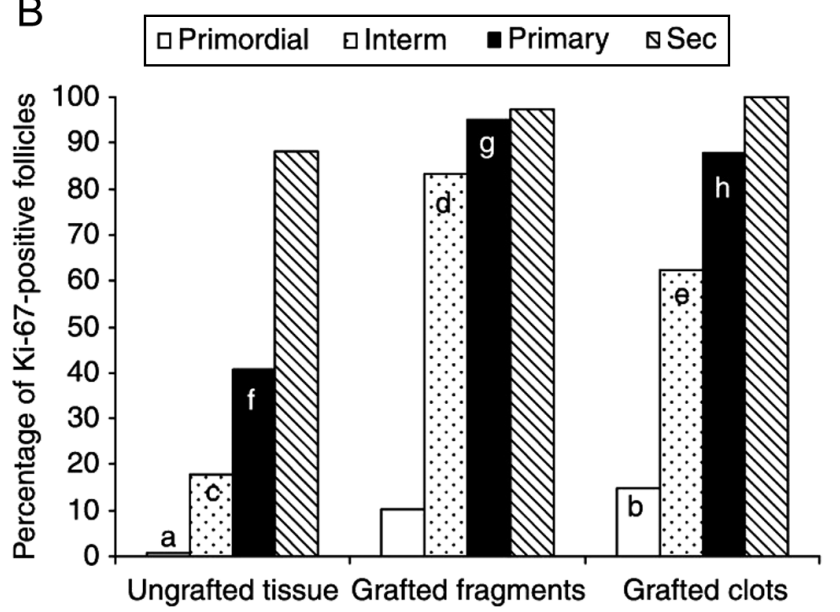

a Significantly different from $b(P<0.05)$

c Significantly different from $\mathrm{d}$ and e $(P<0.001)$

f Significantly different from $\mathrm{g}$ and $\mathrm{h}(P<0.001)$

Figure 2 Increased proliferation seen in early growing follicles in transplanted tissue grafts. (A) Total (including all follicular stages) follicular proliferation rate measured by evaluating the percentage of $\mathrm{Ki}-67$-positive follicles in ungrafted tissue and grafted fragments. (B) Follicular proliferation rate for each follicular stage in the three groups $(c-$ significantly different from $d, P<0.05$. e significantly different from $g, P<0.001)$. Adapted with permission from Dolmans et al. (2007).

post transplantation and could be a significant contributing cause of the loss of reserve in ovarian tissue grafts (Roness et al. 2013, Meirow et al. 2015). This over-recruitment of PMFs in the graft may be triggered by the extensive loss of the growing follicles that results from the mechanical preparation of ovarian tissue strips, the freezing-thawing procedure as well as post-transplantation ischemia. Growing follicles play a vital role in maintaining PMF suppression via the excretion of suppression factors, primarily AMH (Durlinger et al. 2002), and therefore, the loss of growing follicles and the resulting absence of $\mathrm{AMH}$ suppression could be responsible for the mass
PMF activation and follicle growth that occurs post transplantation (Roness et al. 2013).

Mechanical changes to the extracellular environment have also been shown to be involved in regulation of follicle activation. Mechanical fragmentation of ovarian tissue grafts was shown to cause extracellular actin polymerization, inducing disruption of Hippo signaling in the granulosa cells, increasing nuclear localization and decreasing phosphorylation of YAP (Kawamura et al. 2013). The decrease in pYAP-induced proliferation and growth of granulosa cells and follicle activation in fragmented grafts. The importance of the physical environment provided by the extracellular matrix is also highlighted by another recent study which demonstrated that mechanical stress plays a key role in maintaining follicle dormancy and that reduction of this stress triggers follicle activation and growth (Nagamatsu et al. 2019).

\section{Prevention of PMF loss in transplanted grafts}

Different approaches have been used in attempts to reduce follicle loss and optimize OTCP transplantation outcomes addressing different stages of the procedure.

\section{Transplantation site}

While almost all OTCP is performed at orthotopic sites; in the atrophic cortex of the existing ovaries or in peritoneal pockets created in the pelvis, the broad ligament or ovarian fossa, there have been studies which investigated the use of heterotopic sites (Oktay et al. 2001, 2004, Kim et al. 2004a, Demeestere et al. 2007). Heterotopically transplanted grafts have been reported to produce a high number of empty follicles, arrested follicle development $(<15 \mathrm{~mm})$, poor oocyte recovery and low fertilization rates (Dolmans et al. 2009, Greve et al. 2012), possibly due to factors such as environmental temperature, local pressure, paracrine factors and blood supply (Donnez \& Dolmans 2010). Very few live births have been achieved from grafts implanted at heterotopic sites; in one case, transplantation to the abdominal wall actually invaded the abdominal cavity (Stern et al. 2013) and in the second case the graft was placed in the pelvis (Kristensen et al. 2017). Animal studies comparing xenotransplantation into different sites including muscle, fat pad, kidney capsule and subcutaneous (Dath et al. 2010, Youm et al. 2015) uniformly show that orthotopic sites are most favorable and retain the highest percentage of PMFs, and this is supported by clinical results from the centers around the world which demonstrate high success rates performing transplantation to orthotopic sites (Donnez \& Dolmans 2015, Jensen et al. 2015, Meirow et al. 2016).

\section{Graft dimensions}

Graft dimensions have been shown to play a significant role in reducing follicle loss. Thinning the cortical strip 
prior to freezing is critical in order to enable good penetration and evacuation of cryoprotective agents, reduce the likelihood of ice crystal formation and injury and to provide a shorter distance for new blood vessels to traverse to reduce the ischemic period (Gavish et al. 2008). Commonly, (Oktay et al. 2000a) the ovarian cortex is prepared in strips of 1-2 mm thickness; however, in terms of diffusion of oxygen distances greater than $0.2 \mathrm{~mm}$ are generally poorly tolerated (Loffredo \& Lee 2008), and for larger molecules like growth factors and nutrients, diffusion distances are even shorter. It was therefore assumed that reducing graft dimensions and thickness would reduce ischemia by expediting graft vascularization, (Kagawa et al. 2009, Ferreira et al. 2010). Attempts have been made to create thinner grafts - 'micro-organs' - to reduce this distance even further (Revel 2011); however, a xenograft study which directly compared the impact of graft dimensions (Gavish et al. 2014) found that reducing graft thickness does not increase revascularization of the graft. Reducing the thickness of the graft had the additional adverse effect of increasing follicle activation, resulting in increased loss of dormant follicles (Fig. 3). Massive activation related to very small tissue dimensions was highlighted by studies which used fragmentation of graft tissue to increase follicle activation and demonstrated that cutting of the tissue disrupts the Hippo pathway, triggering follicle growth (Kawamura et al. 2013).

\section{Pharmacological methods of reducing transplantation-induced follicle loss}

\section{Reducing ischemic injury}

To reduce ischemic damage during the posttransplantation period, studies have investigated the use of pharmacological treatments which aim either

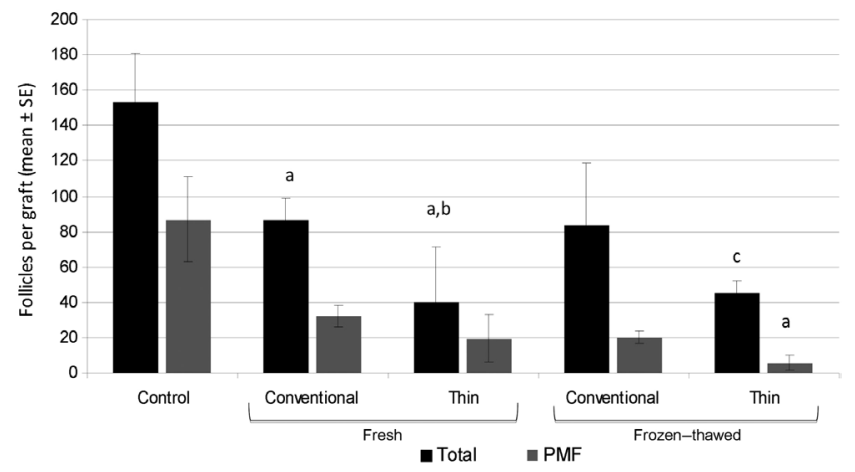

Figure 3 Total follicle (black) and primordial follicle (gray) in thin vs conventional grafts. Comparison of follicle counts in fresh or frozen-thawed thin or conventionally prepared bovine ovarian tissues recovered 7 days post transplantation. Values represent the mean per graft \pm SE. $P<0.05: a=$ compared with control, $b=$ compared with fresh conventional, $\mathrm{c}=$ compared with frozen conventional. (Reprinted with permission from Gavish et al. 2014.) to reduce the time period of ischemia by accelerating graft re-vascularization (with angiogenesis agents) or by reducing the harmful effects of ischemia (with antioxidants, anti-inflammatory and anti-apoptotic agents) (see summary, Table 1). However, only a few of these have been shown to increase PMF survival. Mahmoodi et al. tested two antioxidants; erythropoietin (Mahmoodi et al. 2014) and N-acetylcysteine (Mahmoodi et al. 2015) administered just before and during the first week following transplantation of autografts in mice. They demonstrated almost identical results with each of the treatments, including reduced apoptosis and increased survival of PMFs in grafts which received antioxidant treatment. Both mesenchymal (Xia et al. 2015) and adipose tissue-derived (Manavella et al. 2018) stem cells were shown to increase vascularization and increase PMF survival in xenotransplantation models using human ovarian tissue grafts. Antigenic growth factor basic fibroblast growth factor (bFGF) has been shown to increase angiogenesis and follicle survival in mouse (Gao et al. 2013) and human ovarian tissue grafts (Tanaka et al. 2018). A number of studies looked at another angiogenic growth factor, vascular endothelial growth factor (VEGF), with mixed results; only one study reported an increase in PMF population in VEGF-treated grafts (Shikanov et al. 2011). Culture of ovarian tissue with FSH prior to transplantation was shown to increase VEGF and bFGF expression and vascular density; however, no assessment of follicle numbers was made (Ma et al. 2017).

Other agents which aimed to reduce ischemic injury, such as Vitamin E, S1p, simvastatin and methylprednisolone, were reported in some cases to shorten the ischemic period, reduce apoptosis and improve certain outcomes, but in many cases PMF numbers were not assessed and in others the treatment did not increase follicle survival. The only agent which did result in increased survival of PMFs was verapamil, a calcium channel blocker (Saber et al. 2018); however, the mechanism of action is unclear. The least efficacious were $\mathrm{GnRH}$ agonists, which were hypothesized to prevent PMF loss via downregulation of $\mathrm{LH} / \mathrm{FSH}$ secretion or via angiogenesis (upregulation of VEGF) and in fact increased PMF loss in the grafts (Maltaris et al. 2007).

\section{Reducing follicle activation and loss}

Since the discovery that a contributing factor in follicle loss after transplantation is dysregulated follicle activation (Dath et al. 2010, Amorim et al. 2011), some groups have investigated the possibility of protecting the graft ovarian reserve by preventing this activation (Fig. 4). $\mathrm{AMH}$ is a highly specific suppressor of follicle activation and two recent studies have used recombinant human $\mathrm{AMH}$ in human and mouse models of transplantation with varying degrees of success. One study pretreated the tissue prior to transplantation or injected $\mathrm{AMH}$ 


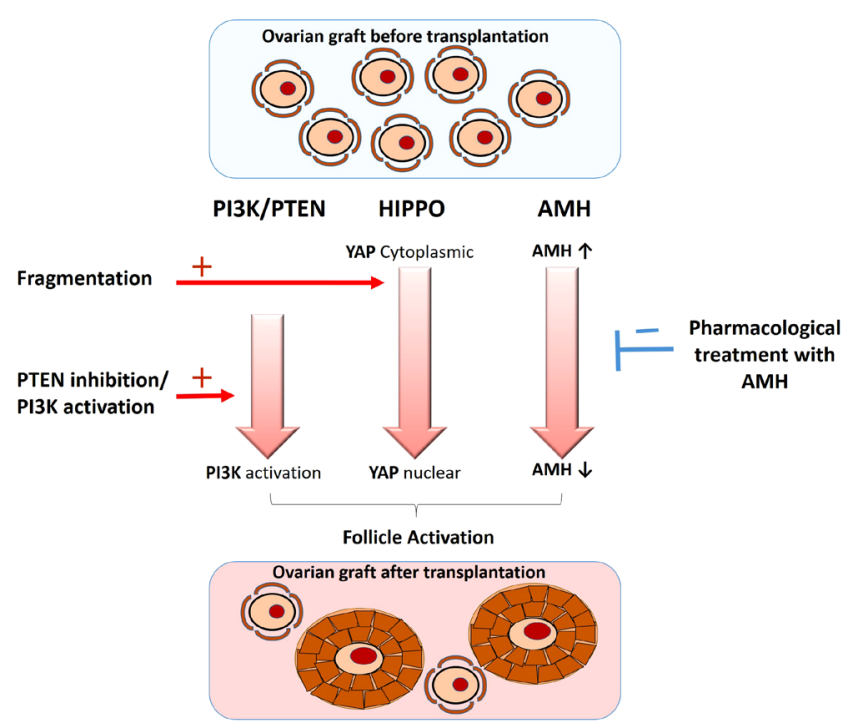

Figure 4 Potential molecular mechanisms and targeted manipulation of follicle activation in ovarian tissue grafts after transplantation. Studies have investigated the role of transplantation-induced activation and loss of dormant follicles in ovarian tissue grafts via three molecular pathways; activation of the Pi3K/PTEN and the Hippo pathway and via reduction in AMH. Targeted manipulation of each of these pathways at the time of transplantation has been shown to impact on the extent of follicle activation in the graft, and thereby on the final dormant follicle reserve remaining in the tissue after transplantation. Fragmentation of the tissue activates the Hippo pathway, phosphorylating YAP which then localizes to the nucleus, increasing follicle activation. Culture of the tissue in the presence of PTEN inhibitors or PI3K pathway activators induces upregulation of the PI3K pathway also resulting in increased follicle activation. Conversely, administration of AMH during transplantation reduces dormant follicle activation, resulting in increased follicle reserve in the graft following transplantation.

into the recipient mouse but found no increase in the primordial follicle reserve as a result of either treatment up to 28 days after transplantation, possibly due to the fact that they injected a relatively low dose of $\mathrm{AMH}$ only every $48 \mathrm{~h}$ (Kong et al. 2016). A second study used continuous treatment of recipient mice with $\mathrm{AMH}$ in intra-abdominal pumps, but also saw no change in graft reserve compared to untreated mice (Detti et al. 2018). Both studies observed reduced apoptosis in $\mathrm{AMH}$-treated grafts, but the data are not strong and additional study is needed since there is no previous indication that $\mathrm{AMH}$ plays any direct role in apoptosis signaling. AMH did, however, prevent transplantation-induced follicle loss in a study which transplanted human ovarian tissue together with exogenous endothelial cells (ExECs) engineered to express AMH (Man et al. 2017). ExEcs alone promoted formation of blood vessels at the interface of graft and host tissue, improving vascularization and reducing fibrosis, but tissue grafts transplanted with AMH-ExECs retained the highest numbers of primordial follicles with fewer growing follicles, indicating that $\mathrm{AMH}$ was suppressing follicular activation. This combined approach which both increases vascularization and reduces follicle activation shows particular potential for reducing follicle loss after transplantation.

\section{Programmed acceleration of follicle activation in grafts}

Rather than reduce follicle loss, an alternative manipulation of OTCP-TP has focused on increasing the activation of dormant follicles within the graft cortical tissue in the immediate short term prior to transplantation to enable collection of mature oocytes for in vitro fertilization. Termed 'in vitro activated' (IVA) OTCP (Kawamura et al. 2013, Suzuki et al. 2015), this method involves fragmentation of the tissue grafts into small cubes of $1-2 \mathrm{~mm}^{2}$, and in vitro culture of the graft fragments with PTEN inhibitor (bisperoxovanadium) and PI3K activator (740YP). Fragmentation promotes actin polymerization within the graft, disrupting Hippo signaling, which promotes follicle growth (Kawamura et al. 2013). Incubation of the tissue with a PTEN inhibitor and a PI3K activator, aims to induce upregulation of the PTEN-PI3K signaling pathway, which has been shown to stimulate activation and growth of dormant primordial follicles both in animal models (Adhikari \& Liu 2009) and in humans (Li et al. 2010) (Fig. 4). While two live births have been achieved using this method (Kawamura et al. 2013, Suzuki et al. 2015), there are safety concerns regarding chemical exposure of the tissue and a recent study reported that ovarian graft exposure to bisperoxovanadium increased DNA damage in oocytes of growing and PMFs and decreased expression of DNA repair proteins (Maidarti et al. 2019). More recent use of IVA has removed the step of chemical activation and focused on tissue fragmentation only, which was found to be sufficient to induce activation (Fabregues et al. 2018). IVA has been conducted on 51 patients, with a total of $5(10 \%)$ resulting pregnancies and $3(6 \%)$ live births. Given that in general, POI patients have unpredictable ovarian function, and reports indicate a 5-10\% rate of spontaneous pregnancy (van Kasteren \& Schoemaker 1999), the success of IVA may not exceed that of no intervention at all.

The promotion of dormant follicle activation, while producing a short-term burst of mature follicles, will also by necessity reduce the PMF population and therefore the lifespan of the graft (Fig. 5). OTCP is currently indicated for use primarily in cancer patients who will autotransplant the tissue once they are in remission. The aim of graft transplantation in such patients is to restore ovarian function for as long as possible, providing the greatest benefit in terms of endocrine function and fertility from each piece of cortex. For this purpose, the loss of large numbers of primordial follicles via activation is counterproductive (Meirow et al. 2015). In contrast, IVA OTCP is currently aimed at treating women with extremely low ovarian reserve and who are therefore 

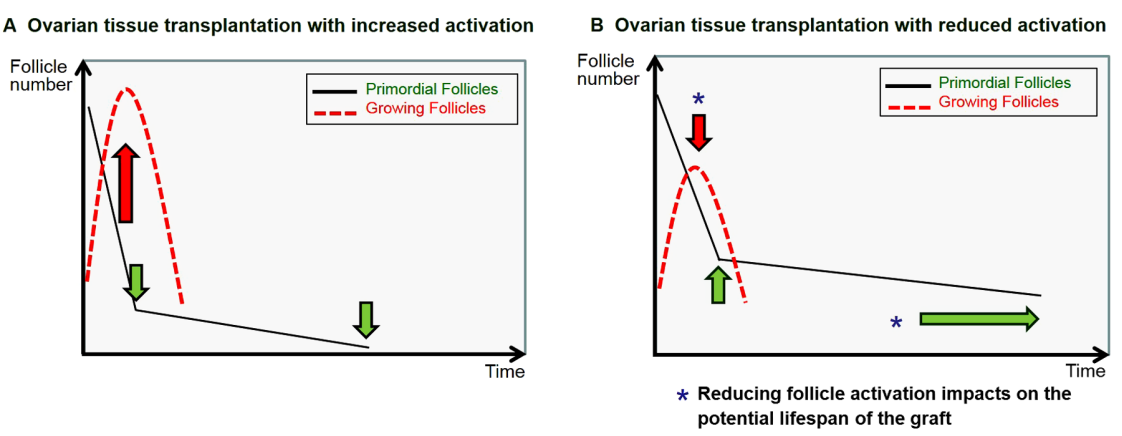

Figure 5 The magnitude of follicle activation directly impacts PMF reserve in ovarian grafts. (A) Inducing activation in ovarian follicle grafts increases the number of growing follicles in the immediate short term at the expense of the PMF population, resulting in decreased graft lifespan. This may be suitable for immediate IVF retrieval but comes at the expense of the overall fertility potential and long-term functioning of the graft. (B) Limiting activation at the time of transplantation reduces PMF loss thereby extending graft lifespan. It is preferable to reduce the activation that occurs with transplantation in order to maximize the fertility outcomes of the procedure. (Reprinted with permission from Gavish et al. 2018.) poor responders to controlled ovarian stimulation (Kawamura et al. 2015). In these women, the acceleration of activation aims to stimulate the few remaining follicles to grow during the immediate time post transplantation.

\section{Intra- and extra-ovarian regulation of follicle recruitment in ovarian grafts}

Given the low numbers of follicles that survive OTCP and transplantation, it is surprising that ovarian grafts can and do last for periods of years, generating repeated pregnancies and live births (Jensen et al. 2015, Meirow et al. 2016). The rate of follicle activation and loss over the course of the human reproductive span is nonlinear and regulated by both intra- and extra-ovarian signaling, controlling a complex interplay between rates of recruitment, growth, selection and atresia (Gougeon 1996, Hansen et al. 2008, Wallace \& Kelsey 2010, Wilkosz et al. 2014). Intra-ovarian regulation of follicle recruitment derives from numerous signals, including the PI3K-PTEN pathway, kit ligand, $\mathrm{AMH}$, nerve growth factor (NGF) and members of the BMP family of proteins. In addition, several studies have suggested that the architecture of the ovary and the density of the population of primordial follicles plays a self-regulating role, such that a reduction in the pool of dormant follicles reduces the rate of recruitment (Krarup et al. 1969, Hirshfield 1994, Gaytan et al. 2015). The influence of extra-ovarian factors is evidenced in studies which look at the age of menopause in patients who underwent unilateral oophorectomy, effectively halving their ovarian reserve. The age at menopause in these patients is surprisingly unaffected by this radical reduction in reserve, with onset only $1-2$ years before the normal age at menopause (Bjelland et al. 2014, Rosendahl et al. 2017), rather than the expected 10-year reduction in fertility that would be predicted if there were no adjustment in follicle recruitment (Wilkosz et al. 2014). This ability of the body to 'adjust' the rate of follicle recruitment to conserve follicles in the case of sudden loss of a large proportion of the ovarian reserve may also play a role in OTCP. It is possible that following the initial acute phase of transplantation, both intraovarian and extra-ovarian regulation factors identify and respond to the limited reserve in the transplanted graft by adjusting the rate of recruitment in order to reduce superfluous follicle activation and loss and maximize the lifespan of that reserve.

\section{Conclusion}

OTCP-TP is increasingly offered as a fertility preservation option to young women undergoing ovotoxic treatments, resulting in a growing number of pregnancies and live births around the world. The objective of OTCP is to restore ovarian function for as long as possible, both in order to enable multiple ovulations and pregnancies and for restoration of endocrine function. Optimization of the procedure therefore focuses on reducing follicle loss in the graft as the basis for extending graft lifespan and productivity. As the vast majority of dormant follicles in the graft are lost following transplantation, developing methods that will reduce follicle loss at this stage is key. Techniques such as reducing graft dimensions or heterotopic grafting have been shown to negatively impact follicle survival and graft functionality. Pharmacological methods that decrease ischemic damage and/or reduce follicle activation can potentially reduce follicle loss after transplantation. Techniques which act to increase follicle activation have been used in specific cases, such as recent onset premature ovarian insufficiency, but with little success. In cases of fertility preservation, IVA will reduce graft lifespan and is therefore not recommended for the majority of women undergoing OTCP. Reducing follicle wastage and thereby increasing the productivity of the procedure will provide greater long-term benefit to these patients.

\section{Declaration of interest}

The authors declare that there is no conflict of interest that could be perceived as prejudicing the impartiality of this review. 


\section{Funding}

Funding was received from the Kahn Foundation, and a grant from Tel Aviv University for Fertility Preservation following chemotherapy in the name of Dr Karen Buzaglo and Alexandre Abecassis.

\section{Author contribution statement}

$\mathrm{HR}$ and D M both conducted the review and wrote the paper.

\section{References}

Abir R, Fisch B, Jessel S, Felz C, Ben-Haroush A \& Orvieto R 2011 Improving post-transplantation survival of human ovarian tissue by treating the host and graft. Fertility and Sterility 95 1205-1210. (https:// doi.org/10.1016/j.fertnstert.2010.07.1082)

Adhikari D \& Liu K 2009 Molecular mechanisms underlying the activation of mammalian primordial follicles. Endocrine Reviews 30 438-464. (https://doi.org/10.1210/er.2008-0048)

Amorim CA, David A, Dolmans MM, Camboni A, Donnez J \& Van Langendonckt A 2011 Impact of freezing and thawing of human ovarian tissue on follicular growth after long-term xenotransplantation. Journal of Assisted Reproduction and Genetics 28 1157-1165. (https://doi. org/10.1007/s10815-011-9672-z)

Andersen CY, Silber SJ, Berghold SH, Jorgensen JS \& Ernst E 2012 Long-term duration of function of ovarian tissue transplants: case reports. Reproductive Biomedicine Online 25 128-132. (https://doi. org/10.1016/j.rbmo.2012.03.014)

Aubard Y, Piver P, Cogni Y, Fermeaux V, Poulin N \& Driancourt MA 1999 Orthotopic and heterotopic autografts of frozen-thawed ovarian cortex in sheep. Human Reproduction 14 2149-2154. (https://doi.org/10.1093/ humrep/14.8.2149)

Aubard Y 2003 Ovarian tissue xenografting. European Journal of Obstetics \& Gynecology and Reproductive Biology 108 14-18. (https://doi.org/ 10.1016/s0301-2115(02)00424-4)

Ayuandari S, Winkler-Crepaz K, Paulitsch M, Wagner C, Zavadil C, Manzl C, Ziehr SC, Wildt L \& Hofer-Tollinger S 2016 Follicular growth after xenotransplantation of cryopreserved/thawed human ovarian tissue in SCID mice: dynamics and molecular aspects. Journal of Assisted Reproduction and Genetics 33 1585-1593. (https://doi.org/10.1007/ s10815-016-0769-2)

Baird DT, Webb R, Campbell BK, Harkness LM \& Gosden RG 1999 Longterm ovarian function in sheep after ovariectomy and transplantation of autografts stored at -196 C. Endocrinology 140 462-471. (https://doi. org/10.1210/endo.140.1.6453)

Bjelland EK, Wilkosz P, Tanbo TG \& Eskild A 2014 Is unilateral oophorectomy associated with age at menopause? A population study (the HUNT2 Survey). Human Reproduction 29 835-841. (https://doi. org/10.1093/humrep/deu026)

Bols PE, Aerts JM, Langbeen A, Goovaerts IG \& Leroy JL 2010 Xenotransplantation in immunodeficient mice to study ovarian follicular development in domestic animals. Theriogenology 73 740-747. (https:// doi.org/10.1016/j.theriogenology.2009.10.002)

Cacciottola L, Manavella DD, Amorim CA, Donnez J \& Dolmans MM 2018 In vivo characterization of metabolic activity and oxidative stress in grafted human ovarian tissue using microdialysis. Fertility and Sterility 110 534.e3-544.e3. (https://doi.org/10.1016/j.fertnstert.2018.04.009)

Camboni A, Martinez-Madrid B, Dolmans MM, Nottola S, Van Langendonckt A \& Donnez J 2008 Autotransplantation of frozen-thawed ovarian tissue in a young woman: ultrastructure and viability of grafted tissue. Fertility and Sterility 90 1215-1218. (https://doi.org/10.1016/j. fertnstert.2007.08.084)

Candy CJ, Wood MJ \& Whittingham DG 1997 Effect of cryoprotectants on the survival of follicles in frozen mouse ovaries. Journal of Reproduction and Fertility 110 11-19. (https://doi.org/ 10.1530/jrf.0.1100011)

Commin L, Buff S, Rosset E, Galet C, Allard A, Bruyere P, Joly T, Guerin P \& Neto V 2012 Follicle development in cryopreserved bitch ovarian tissue grafted to immunodeficient mouse. Reproduction, Fertility, and Development 24 461-471. (https://doi.org/10.1071/RD11166)
Damous LL, Nakamuta JS, de Carvalho AE, Soares JM Jr, de Jesus Simões M, Krieger JE \& Baracat EC 2015 Adipose tissue-derived stem cell therapy in rat cryopreserved ovarian grafts. Stem Cell Research \& Therapy 657. (https://doi.org/10.1186/s13287-015-0068-3)

Dath C, Van Eyck AS, Dolmans MM, Romeu L, Delle Vigne L, Donnez J \& Van Langendonckt A 2010 Xenotransplantation of human ovarian tissue to nude mice: comparison between four grafting sites. Human Reproduction 25 1734-1743. (https://doi.org/10.1093/humrep/deq131)

Demeestere I, Simon P, Emiliani S, Delbaere A \& Englert Y 2007 Fertility preservation: successful transplantation of cryopreserved ovarian tissue in a young patient previously treated for Hodgkin's disease. Oncologist 12 1437-1442. (https://doi.org/10.1634/theoncologist.12-12-1437)

Demeestere I, Simon P, Emiliani S, Delbaere A \& Englert Y 2009 Orthotopic and heterotopic ovarian tissue transplantation. Human Reproduction Update 15 649-665. (https://doi.org/10.1093/humupd/dmp021)

Detti L, Fletcher NM, Saed GM, Sweatman TW, Uhlmann RA, Pappo A \& Peregrin-Alvarez I 2018 Xenotransplantation of pre-pubertal ovarian cortex and prevention of follicle depletion with anti-Mullerian hormone (AMH). Journal of Assisted Reproduction and Genetics 35 1831-1841. (https://doi.org/10.1007/s10815-018-1260-z)

Dolmans MM, Martinez-Madrid B, Gadisseux E, Guiot Y, Yuan WY, Torre A, Camboni A, Van Langendonckt A \& Donnez J 2007 Short-term transplantation of isolated human ovarian follicles and cortical tissue into nude mice. Reproduction 134 253-262. (https://doi.org/10.1530/ REP-07-0131)

Dolmans MM, Donnez J, Camboni A, Demylle D, Amorim C, Van Langendonckt A \& Pirard C 2009 IVF outcome in patients with orthotopically transplanted ovarian tissue. Human Reproduction 24 2778-2787. (https://doi.org/10.1093/humrep/dep289)

Donnez J \& Dolmans MM 2010 Cryopreservation and transplantation of ovarian tissue. Clinical Obstetrics and Gynecology 53 787-796. (https:// doi.org/10.1097/GRF.0b013e3181f97a55)

Donnez J \& Dolmans MM 2015 Ovarian cortex transplantation: 60 reported live births brings the success and worldwide expansion of the technique towards routine clinical practice. Journal of Assisted Reproduction and Genetics 32 1167-1170. (https://doi.org/10.1007/s10815-015-0544-9)

Donnez J, Dolmans MM, Demylle D, Jadoul P, Pirard C, Squifflet J, Martinez-Madrid B \& van Langendonckt A 2004 Livebirth after orthotopic transplantation of cryopreserved ovarian tissue. Lancet 364 1405-1410. (https://doi.org/10.1016/S0140-6736(04)17222-X)

Donnez J, Dolmans MM, Pellicer A, Diaz-Garcia C, Sanchez Serrano M, Schmidt KT, Ernst E, Luyckx V \& Andersen CY 2013 Restoration of ovarian activity and pregnancy after transplantation of cryopreserved ovarian tissue: a review of 60 cases of reimplantation. Fertility and Sterility 99 1503-1513. (https://doi.org/10.1016/j.fertnstert.2013.03.030)

Durlinger AL, Visser JA \& Themmen AP 2002 Regulation of ovarian function: the role of anti-Mullerian hormone. Reproduction 124 601609. (https://doi.org/10.1530/rep.0.1240601)

Fabregues F, Ferreri J, Calafell JM, Moreno V, Borras A, Manau D \& Carmona F 2018 Pregnancy after drug-free in vitro activation of follicles and fresh tissue autotransplantation in primary ovarian insufficiency patient: a case report and literature review. Journal of Ovarian Research 11 76. (https://doi.org/10.1186/s13048-018-0447-3)

Ferreira M, Bos-Mikich A, Frantz N, Rodrigues JL, Brunetto AL \& Schwartsmann G 2010 The effects of sample size on the outcome of ovarian tissue cryopreservation. Reproduction in Domestic Animals 45 99-102. (https://doi.org/10.1111/j.1439-0531.2008.01261.x)

Friedman O, Orvieto R, Fisch B, Felz C, Freud E, Ben-Haroush A \& Abir R 2012 Possible improvements in human ovarian grafting by various host and graft treatments. Human Reproduction 27 474-482. (https://doi. org/10.1093/humrep/der385)

Gao JM, Yan J, Li R, Li M, Yan LY, Wang TR, Zhao HC, Zhao Y, Yu Y \& Qiao J 2013 Improvement in the quality of heterotopic allotransplanted mouse ovarian tissues with basic fibroblast growth factor and fibrin hydrogel. Human Reproduction 28 2784-2793. (https://doi.org/ 10.1093/humrep/det296)

Gavish Z, Ben-Haim M \& Arav A 2008 Cryopreservation of whole murine and porcine livers. Rejuvenation Research 11 765-772. (https://doi. org/10.1089/rej.2008.0706)

Gavish Z, Peer G, Roness H, Cohen Y \& Meirow D 2014 Follicle activation and 'burn-out' contribute to post-transplantation follicle loss in ovarian tissue grafts: the effect of graft thickness. Human Reproduction 29989 996. (https://doi.org/10.1093/humrep/deu015) 
Gavish Z, Spector I, Peer G, Schlatt S, Wistuba I, Roness H \& Meirow D 2018 Follicle activation is a significant and immediate cause of follicle loss after ovarian tissue transplantation. Journal of Assisted Reproduction and Genetics 35 61-69. (https://doi.org/10.1007/s10815-017-1079-z)

Gaytan F, Morales C, Leon S, Garcia-Galiano D, Roa J \& Tena-Sempere M 2015 Crowding and follicular fate: spatial determinants of follicular reserve and activation of follicular growth in the mammalian ovary. PLoS ONE 10 e0144099. (https://doi.org/10.1371/journal.pone.0144099)

Gellert SE, Pors SE, Kristensen SG, Bay-Bjorn AM, Ernst E \& Yding Andersen C 2018 Transplantation of frozen-thawed ovarian tissue: an update on worldwide activity published in peer-reviewed papers and on the Danish cohort. Journal of Assisted Reproduction and Genetics 35 561-570. (https://doi.org/10.1007/s10815-018-1144-2)

Gosden RG \& Byatt-Smith JG 1986 Oxygen concentration gradient across the ovarian follicular epithelium: model, predictions and implications. Human Reproduction 1 65-68. (https://doi.org/ 10.1093/oxfordjournals. humrep.a136362)

Gosden RG, Baird DT, Wade JC \& Webb R 1994 Restoration of fertility to oophorectomized sheep by ovarian autografts stored at -196 degrees C. Human Reproduction 9 597-603. (https://doi.org/10.1093/ oxfordjournals.humrep.a138556)

Gosden RG, Mullan J, Picton HM, Yin H \& Tan SL 2002 Current perspective on primordial follicle cryopreservation and culture for reproductive medicine. Human Reproduction Update 8 105-110. (https://doi. org/10.1093/humupd/8.2.105)

Gougeon A 1986 Dynamics of follicular growth in the human: a model from preliminary results. Human Reproduction 1 81-87. (https://doi. org/10.1093/oxfordjournals.humrep.a136365)

Gougeon A 1996 Regulation of ovarian follicular development in primates: facts and hypotheses. Endocrine Reviews 17 121-155. (https://doi. org/10.1210/edrv-17-2-121)

Greve T, Schmidt KT, Kristensen SG, Ernst E \& Andersen CY 2012 Evaluation of the ovarian reserve in women transplanted with frozen and thawed ovarian cortical tissue. Fertility and Sterility 97 1394.e1-1398. e1. (https://doi.org/10.1016/j.fertnstert.2012.02.036)

Hancke K, Walker E, Strauch O, Gobel H, Hanjalic-Beck A \& Denschlag D 2009 Ovarian transplantation for fertility preservation in a sheep model: can follicle loss be prevented by antiapoptotic sphingosine-1-phosphate administration? Gynecological Endocrinology 25 839-843. (https://doi. org/10.3109/09513590903159524)

Hansen KR, Knowlton NS, Thyer AC, Charleston JS, Soules MR \& Klein NA 2008 A new model of reproductive aging: the decline in ovarian nongrowing follicle number from birth to menopause. Human Reproduction 23 699-708. (https://doi.org/10.1093/humrep/dem408)

Harris SE, Leese HJ, Gosden RG \& Picton HM 2009 Pyruvate and oxygen consumption throughout the growth and development of murine oocytes. Molecular Reproduction and Development 76 231-238. (https://doi.org/10.1002/mrd.20945)

Hirshfield AN 1994 Relationship between the supply of primordial follicles and the onset of follicular growth in rats. Biology of Reproduction $\mathbf{5 0}$ $421-428$.

Israely T, Dafni H, Nevo N, Tsafriri A \& Neeman M 2004 Angiogenesis in ectopic ovarian xenotransplantation: multiparameter characterization of the neovasculature by dynamic contrast-enhanced MRI. Magnetic Resonance in Medicine 52 741-750. (https://doi.org/10.1002/mrm.20203)

Jensen AK, Kristensen SG, Macklon KT, Jeppesen JV, Fedder J, Ernst E \& Andersen CY 2015 Outcomes of transplantations of cryopreserved ovarian tissue to 41 women in Denmark. Human Reproduction 30 2838-2845. (https://doi.org/10.1093/humrep/dev230)

Kagawa N, Silber S \& Kuwayama M 2009 Successful vitrification of bovine and human ovarian tissue. Reproductive Biomedicine Online 18 568577. (https://doi.org/10.1016/S1472-6483(10)60136-8)

Kawamura K, Cheng Y, Suzuki N, Deguchi M, Sato Y, Takae S, Ho CH, Kawamura N, Tamura M, Hashimoto S et al. 2013 Hippo signaling disruption and Akt stimulation of ovarian follicles for infertility treatment. PNAS 110 17474-17479. (https://doi.org/10.1073/pnas.1312830110)

Kawamura K, Cheng Y, Sun YP, Zhai J, Diaz-Garcia C, Simon C, Pellicer A \& Hsueh AJ 2015 Ovary transplantation: to activate or not to activate. Human Reproduction 30 2457-2460. (https://doi.org/10.1093/humrep/dev211)

Kim SS, Hwang IT \& Lee HC 2004a Heterotopic autotransplantation of cryobanked human ovarian tissue as a strategy to restore ovarian function. Fertility and Sterility 82 930-932. (https://doi.org/10.1016/j. fertnstert.2004.02.137)
Kim SS, Yang HW, Kang HG, Lee HH, Lee HC, Ko DS \& Gosden RG $2004 b$ Quantitative assessment of ischemic tissue damage in ovarian cortical tissue with or without antioxidant (ascorbic acid) treatment. Fertility and Sterility 82 679-685. (https://doi.org/10.1016/j.fertnstert.2004.05.022)

Kong HS, Kim SK, Lee J, Youm HW, Lee JR, Suh CS \& Kim SH 2016 Effect of exogenous anti-Mullerian hormone treatment on cryopreserved and transplanted mouse ovaries. Reproductive Sciences 23 51-60. (https:// doi.org/10.1177/1933719115594021)

Krarup T, Pedersen T \& Faber M 1969 Regulation of oocyte growth in the mouse ovary. Nature 224 187-188. (https://doi.org/10.1038/224187a0)

Kristensen SG, Giorgione V, Humaidan P, Alsbjerg B, Bjorn AB, Ernst E \& Andersen CY 2017 Fertility preservation and refreezing of transplanted ovarian tissue-a potential new way of managing patients with low risk of malignant cell recurrence. Fertility and Sterility 107 1206-1213. (https:// doi.org/10.1016/j.fertnstert.2017.03.017)

Labied S, Delforge Y, Munaut C, Blacher S, Colige A, Delcombel R, Henry L, Fransolet M, Jouan C, Perrier d'Hauterive S et al. 2013 Isoform 111 of vascular endothelial growth factor (VEGF111) improves angiogenesis of ovarian tissue xenotransplantation. Transplantation 95 426-433. (https://doi.org/ 10.1097/TP.0b013e318279965c)

Lee J, Kim EJ, Kong HS, Youm HW, Lee JR, Suh CS \& Kim SH 2015 A combination of simvastatin and methylprednisolone improves the quality of vitrified-warmed ovarian tissue after auto-transplantation. Human Reproduction 30 2627-2638. (https://doi.org/10.1093/humrep/dev222)

Lee J, Kong HS, Kim EJ, Youm HW, Lee JR, Suh CS \& Kim SH 2016 Ovarian injury during cryopreservation and transplantation in mice: a comparative study between cryoinjury and ischemic injury. Human Reproduction 31 1827-1837. (https://doi.org/10.1093/humrep/dew144)

Li J, Kawamura K, Cheng Y, Liu S, Klein C, Liu S, Duan EK \& Hsueh AJ 2010 Activation of dormant ovarian follicles to generate mature eggs. PNAS 107 10280-10284. (https://doi.org/10.1073/pnas.1001198107)

Liu J, Van der Elst J, Van den Broecke R \& Dhont M 2002 Early massive follicle loss and apoptosis in heterotopically grafted newborn mouse ovaries. Human Reproduction 17 605-611. (https://doi.org/10.1093/ humrep/17.3.605)

Liu L, Wood GA, Morikawa L, Ayearst R, Fleming C \& McKerlie C 2008 Restoration of fertility by orthotopic transplantation of frozen adult mouse ovaries. Human Reproduction 23 122-128. (https://doi.org/ 10.1093/humrep/dem348)

Loffredo F \& Lee RT 2008 Therapeutic vasculogenesis: it takes two. Circulation Research 103 128-130. (https://doi.org/10.1161/ CIRCRESAHA.108.180604)

Ma WZ, Zheng XM, Hei CC, Zhao CJ, Xie SS, Chang Q, Cai YF, Jia H, Pei XY \& Wang YR 2017 Optimal FSH usage in revascularization of allotransplanted ovarian tissue in mice. Journal of Ovarian Research 10 5. (https://doi.org/10.1186/s13048-016-0299-7)

Mahmoodi M, Soleimani Mehranjani M, Shariatzadeh SM, Eimani H \& Shahverdi A 2014 Effects of erythropoietin on ischemia, follicular survival, and ovarian function in ovarian grafts. Reproduction $147733-$ 741. (https://doi.org/10.1530/REP-13-0379)

Mahmoodi M, Soleimani Mehranjani M, Shariatzadeh SM, Eimani H \& Shahverdi A $2015 \mathrm{~N}$-acetylcysteine improves function and follicular survival in mice ovarian grafts through inhibition of oxidative stress. Reproductive Biomedicine Online 30 101-110. (https://doi. org/10.1016/j.rbmo.2014.09.013)

Maidarti M, Clarkson YL, McLaughlin M, Anderson RA \& Telfer EE 2019 Inhibition of PTEN activates bovine non-growing follicles in vitro but increases DNA damage and reduces DNA repair response. Human Reproduction 34 297-307. (https://doi.org/10.1093/humrep/dey354)

Maltaris T, Beckmann MW, Binder H, Mueller A, Hoffmann I, Koelbl H \& Dittrich R 2007 The effect of a GnRH agonist on cryopreserved human ovarian grafts in severe combined immunodeficient mice. Reproduction 133 503-509. (https://doi.org/10.1530/REP-06-0061)

Man L, Park L, Bodine R, Ginsberg M, Zaninovic N, Man OA, Schattman G, Rosenwaks Z \& James D 2017 Engineered endothelium provides angiogenic and paracrine stimulus to grafted human ovarian tissue. Scientific Reports 7 8203. (https://doi.org/10.1038/s41598-017-08491-z)

Manavella DD, Cacciottola L, Pomme S, Desmet CM, Jordan BF, Donnez J, Amorim CA \& Dolmans MM 2018 Two-step transplantation with adipose tissue-derived stem cells increases follicle survival by enhancing vascularization in xenografted frozen-thawed human ovarian tissue. Human Reproduction 33 1107-1116. (https://doi.org/10.1093/humrep/ dey080) 
Martinez-Madrid B, Donnez J, Van Eyck AS, Veiga-Lopez A, Dolmans MM \& Van Langendonckt A 2009 Chick embryo chorioallantoic membrane (CAM) model: a useful tool to study short-term transplantation of cryopreserved human ovarian tissue. Fertility and Sterility 91 285-292. (https://doi.org/10.1016/j.fertnstert.2007.11.026)

McCord JM 1985 Oxygen-derived free radicals in postischemic tissue injury. New England Journal of Medicine 312 159-163. (https://doi. org/10.1056/NEJM198501173120305)

Meirow D, Levron J, Eldar-Geva T, Hardan I, Fridman E, Zalel Y, Schiff E \& Dor J 2005 Pregnancy after transplantation of cryopreserved ovarian tissue in a patient with ovarian failure after chemotherapy. New England Journal of Medicine 353 318-321. (https://doi.org/10.1056/NEJMc055237)

Meirow D, Roness H, Kristensen SG \& Andersen CY 2015 Optimizing outcomes from ovarian tissue cryopreservation and transplantation; activation versus preservation. Human Reproduction 30 2453-2456. (https://doi.org/10.1093/humrep/dev210)

Meirow D, Ra'anani H, Shapira M, Brenghausen M, Derech Chaim S, AvielRonen S, Amariglio N, Schiff E, Orvieto R \& Dor J 2016 Transplantations of frozen-thawed ovarian tissue demonstrate high reproductive performance and the need to revise restrictive criteria. Fertility and Sterility 106 467-474. (https://doi.org/10.1016/j.fertnstert.2016.04.031)

Nagamatsu G, Shimamoto S, Hamazaki N, Nishimura Y \& Hayashi K 2019 Mechanical stress accompanied with nuclear rotation is involved in the dormant state of mouse oocytes. Science Advances 5 eaav9960. (https:// doi.org/10.1126/sciadv.aav9960)

Newton H, Aubard Y, Rutherford A, Sharma V \& Gosden R 1996 Low temperature storage and grafting of human ovarian tissue. Human Reproduction 11 1487-1491. (https://doi.org/10.1093/oxfordjournals. humrep.a019423)

Nugent D, Newton H, Gallivan L \& Gosden RG 1998 Protective effect of vitamin $\mathrm{E}$ on ischaemia-reperfusion injury in ovarian grafts. Journal of Reproduction and Fertility 114 341-346. (https://doi.org/10.1530/ jrf.0.1140341)

Oktay K, Karlikaya GG \& Aydin BA 2000a Ovarian cryopreservation and transplantation: basic aspects. Molecular and Cellular Endocrinology 169 105-108. (https://doi.org/10.1016/S0303-7207(00)00361-0)

Oktay K, Newton H \& Gosden RG 2000b Transplantation of cryopreserved human ovarian tissue results in follicle growth initiation in SCID mice. Fertility and Sterility 73 599-603. (https://doi.org/10.1016/s00150282(99)00548-8)

Oktay K, Economos K, Kan M, Rucinski J, Veeck L \& Rosenwaks Z 2001 Endocrine function and oocyte retrieval after autologous transplantation of ovarian cortical strips to the forearm. JAMA 286 1490-1493. (https:// doi.org/10.1001/jama.286.12.1490)

Oktay K, Buyuk E, Veeck L, Zaninovic N, Xu K, Takeuchi T, Opsahl M \& Rosenwaks Z 2004 Embryo development after heterotopic transplantation of cryopreserved ovarian tissue. Lancet 363 837-840. (https://doi.org/10.1016/S0140-6736(04)15728-0)

Revel A, Laufer N, Ben Meir A, Lebovich M \& Mitrani E 2011 Microorgan ovarian transplantation enables pregnancy: a case report. Human Reproduction 26 1097-1103. (https://doi.org/10.1093/humrep/der063)

Rodriguez-Wallberg KA, Tanbo T, Tinkanen $H$, Thurin-Kjellberg A, Nedstrand E, Kitlinski ML, Macklon KT, Ernst E, Fedder J, Tiitinen A et al. 2016 Ovarian tissue cryopreservation and transplantation among alternatives for fertility preservation in the Nordic countries - compilation of 20 years of multicenter experience. Acta Obstetricia and Gynecologica Scandinavica 95 1015-1026. (https://doi.org/10.1111/aogs.12934)

Roness H, Gavish Z, Cohen Y \& Meirow D 2013 Ovarian follicle burnout: a universal phenomenon? Cell Cycle 12 3245-3246. (https://doi. org/10.4161/CC.26358)

Rosendahl M, Simonsen MK \& Kjer J 2017 The influence of unilateral oophorectomy on the age of menopause. Climacteric 20 540-544. (https://doi.org/10.1080/13697137.2017.1369512)

Saber M, Eimani H, Soleimani Mehranjani M, Shahverdi A, Momeni HR, Fathi R \& Tavana S 2018 The effect of verapamil on ischaemia/ reperfusion injury in mouse ovarian tissue transplantation. Biomedicine and Pharmacotherapy 108 1313-1319. (https://doi.org/10.1016/j. biopha.2018.09.130)

Shikanov A, Zhang Z, Xu M, Smith RM, Rajan A, Woodruff TK \& Shea LD 2011 Fibrin encapsulation and vascular endothelial growth factor delivery promotes ovarian graft survival in mice. Tissue Engineering: Part A 17 3095-3104. (https://doi.org/10.1089/ten.TEA.2011.0204)
Silber S, Pineda J, Lenahan K, DeRosa M \& Melnick J 2015 Fresh and cryopreserved ovary transplantation and resting follicle recruitment. Reproductive Biomedicine Online 30 643-650. (https://doi.org/ 10.1016/j.rbmo.2015.02.010)

Silber S 2016 Ovarian tissue cryopreservation and transplantation: scientific implications. Journal of Assisted Reproduction and Genetics 33 1595-1603. (https://doi.org/10.1007/s10815-016-0814-1)

Soleimani R, Heytens E \& Oktay K 2011 Enhancement of neoangiogenesis and follicle survival by sphingosine-1-phosphate in human ovarian tissue xenotransplants. PLOS One 6 e19475. (https://doi.org/10.1371/ journal.pone.0019475)

Stern CJ, Gook D, Hale LG, Agresta F, Oldham J, Rozen G \& Jobling T 2013 First reported clinical pregnancy following heterotopic grafting of cryopreserved ovarian tissue in a woman after a bilateral oophorectomy. Human Reproduction 28 2996-2999. (https://doi.org/10.1093/humrep/ $\operatorname{det} 360$ )

Suzuki N, Yoshioka N, Takae S, Sugishita Y, Tamura M, Hashimoto S, Morimoto Y \& Kawamura K 2015 Successful fertility preservation following ovarian tissue vitrification in patients with primary ovarian insufficiency. Human Reproduction 30 608-615. (https://doi. org/10.1093/humrep/deu353)

Tanaka A, Nakamura H, Tabata Y, Fujimori Y, Kumasawa K \& Kimura T 2018 Effect of sustained release of basic fibroblast growth factor using biodegradable gelatin hydrogels on frozen-thawed human ovarian tissue in a xenograft model. Journal of Obstetrics and Gynaecology Research 44 1947-1955. (https://doi.org/10.1111/jog.13726)

Van Eyck AS, Jordan BF, Gallez B, Heilier JF, Van Langendonckt A \& Donnez J 2009 Electron paramagnetic resonance as a tool to evaluate human ovarian tissue reoxygenation after xenografting. Fertility and Sterility 92 374-381. (https://doi.org/10.1016/j.fertnstert.2008.05.012)

Van Eyck AS, Bouzin C, Feron O, Romeu L, Van Langendonckt A, Donnez J \& Dolmans MM 2010 Both host and graft vessels contribute to revascularization of xenografted human ovarian tissue in a murine model. Fertility and Sterility 93 1676-1685. (https://doi.org/10.1016/j. fertnstert.2009.04.048)

van Kasteren YM \& Schoemaker J 1999 Premature ovarian failure: a systematic review on therapeutic interventions to restore ovarian function and achieve pregnancy. Human Reproduction Update 5 483492. (https://doi.org/10.1093/humupd/5.5.483)

von Schonfeldt V, Chandolia R, Ochsenkuhn R, Nieschlag E, Kiesel L \& Sonntag B 2012 FSH prevents depletion of the resting follicle pool by promoting follicular number and morphology in fresh and cryopreserved primate ovarian tissues following xenografting. Reproductive Biology and Endocrinology 10 98. (https://doi.org/10.1186/1477-7827-10-98)

Wallace WH \& Kelsey TW 2010 Human ovarian reserve from conception to the menopause. PLOS ONE 5 e8772. (https://doi.org/10.1371/journal. pone.0008772)

Wang L, Ying YF, Ouyang YL, Wang JF \& Xu J 2013 VEGF and bFGF increase survival of xenografted human ovarian tissue in an experimental rabbit model. Journal of Assisted Reproduction and Genetics 30 13011311. (https://doi.org/ 10.1007/s10815-013-0043-9)

Wilkosz P, Greggains GD, Tanbo TG \& Fedorcsak P 2014 Female reproductive decline is determined by remaining ovarian reserve and age. PLOS ONE 9 e108343. (https://doi.org/10.1371/journal.pone.0108343)

Xia X, Yin T, Yan J, Yan L, Jin C, Lu C, Wang T, Zhu X, Zhi X, Wang J et al. 2015 Mesenchymal stem cells enhance angiogenesis and follicle survival in human cryopreserved ovarian cortex transplantation. Cell Transplantation 24 1999-2010. (https://doi.org/10.3727/096368914X685267)

Youm HW, Lee JR, Lee J, Jee BC, Suh CS \& Kim SH 2015 Transplantation of mouse ovarian tissue: comparison of the transplantation sites. Theriogenology 83 854-861. (https://doi.org/10.1016/j. theriogenology.2014.11.026)

Received 3 March 2019

First decision 2 April 2019

Revised manuscript received 22 July 2019

Accepted 8 August 2019 